\title{
Analysis The Effect of Bidding Process on Project Performance in PT Pelabuhan Indonesia III (Persero)
}

\author{
Gita Prestalita ${ }^{1}$, I Putu Artama Wiguna ${ }^{2}$, Vita Ratnasari ${ }^{3}$ \\ ${ }^{1}$ Department of Technology Management, Institut Teknologi Sepuluh Nopember, Surabaya \\ ${ }^{2}$ Department of Civil Engineering, Institut Teknologi Sepuluh Nopember, Surabaya \\ ${ }^{3}$ Department of Statistics, Institut Teknologi Sepuluh Nopember, Surabaya \\ e-mail: gitaits@gmail.com
}

\begin{abstract}
Based on investment data in PT Pelabuhan Indonesia III (Persero) with asset code road and construction, also port facility construction in PT Pelabuhan Indonesia III (Persero) 2017 - 2018, there are 65 projects of physical construction. In the bidding process, to assess competence and business ability, also other requirements from the provider with stages of administration evaluation, technical evaluation and bid price from contractor. In 65 investment projects there are 18 projects fined. This research took 65 samples. While secondary data was collected from document of eligible awards of bidding on investment project in 2017-2018 in PT Pelabuhan Indonesia III (Persero) with asset code road and construction, also port facility. Analysis used was Structural Equation Modeling (SEM). The result of this research conclude that bidding process significantly affects to project performance variable.
\end{abstract}

Keywords - Bidding Process, Project Performance, SEM.

\section{INTRODUCTION}

B IDDING process in PT Pelindo III based on the procedures of procurement of goods and/or services no: PER.0001/LG.0202/HOFC-2018 date 17 April 2018. In determining the procurement system regulated in Chapter IV concerning establishment of procurement system, that for project with value of 0 to $10 \mathrm{M}$ should use limited poll system. While project with value of $\geq 10 \mathrm{M}$ should use public poll system. To assess competence and business ability also other specific requirements fulfillment from the provider of goods/services, pre-qualification and post-qualification systems can be used. While other things related to price bidding evaluation mentioned above specifically in Chapter $\mathrm{V}$ item $\mathrm{C}$ explains that criteria and evaluation procedures are through administrative and technical evaluations. Technical evaluation is done to offers that fulfill administrative requirements dan is stated qualified if the passing grade is $\geq 60 \%$.

Based on investment data in PT Pelabuhan Indonesia III (Persero) asset code road and building also port facility building in PT Pelabuhan Indonesia III (Persero) year 20172018 , there were 65 physical construction programs with bidding price range of $65 \%-80 \%$ is $23 \%$ from $\mathrm{HPS} / \mathrm{OE}$, bidding price range of $80 \%-90 \%$ is $29 \%$ from HPS/OE, and bidding price range of $90 \%-100 \%$ is $48 \%$ from $\mathrm{HPS} / \mathrm{OE}$. After bidding process, to insure a project goes well, a team of Project Unit was formed to execute, monitor, control and maintain the management standard of a project. From 65 programs of investment project in 2017-2018 executed, there were 18 projects (around 28\%) were fined because couple of reasons i.e the contractor could not finish the project on time; the contractor did not have sufficient funding which compromise the cash flow of the project finance; the contractor could not bring in materials on time which affects the total time of the project execution. From 20 fined projects, obtained in the bidding rocess that contractor bidding price range of $65 \%-80 \%$ was $6 \%$ from $\mathrm{HPS} / \mathrm{OE}$, bidding price range of $80 \%-90 \%$ was $6 \%$ from HPS/OE, and bidding price range of $90 \%-100 \%$ was $15 \%$ from $\mathrm{HPS} / \mathrm{OE}$. Based on that data, price range offering close to HPS/OE does not guarantee that the contractor will do good performance.

According to Eriksson and M. Westerberg, there are few bidding procedures affecting project performance which include design stage, type of bidding, tender evaluation, subcontractor selection, type of payment, and collaboration tools [1]. Astana and Wibowo stated that factors influence bidding strategy are divided into three group i.e external, internal and environmental factors [2]. All factors are determinant in helping contractor to be more focus in developing their bidding process in which better performance can be achieved. In accordance to Umulisa et al., that if a company owns resources, it will allow them to achieve competitive excellence [3]. Those resources includes human resource, finance resource and tool and material resources.

According to Astana and Wibowo, principally, bidding strategy not only to win the competition but also to deliver optimal project performance [2]. In accordance with other literature Wibowo et al., when contractor faced with price bidding stage, volume calculation has to be done right and careful, and also unit price calculation has to consider all influencing factor [4]. Because of that, contractor which bid high quality price, is expected to not only win the competition but also deliver maximum performance. The success of a project is measured by performance. Performance measurement system is used as information to set up strategy of important process that measure efficiency and effectiveness [5].

Soemardi et al, stated that project performance indicators are cost, time, quality, productivity, safety and environment, despite the fact that bidding strategy in construction defines management expertise to make use of all available resources to offer comprehensive and competitive bidding [6]. Therefore, considering every aspect including internal, external and environment, the purpose is to win the bidding competition and give maximum project performance. 
The $1^{\text {st }}$ International Conference on Business and Engineering Management (IConBEM)

February $1^{\text {st }} 2020$, Institut Teknologi Sepuluh Nopember, Surabaya, Indonesia

Table 1.

Laten Eksogen Variable

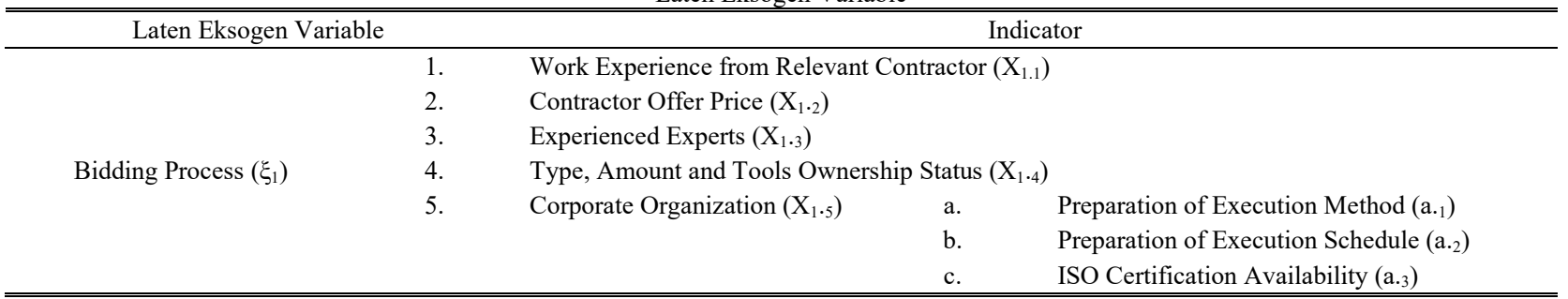

Remarks:

1. $\mathrm{X}_{1.5}$ is the indicator which came from $\mathrm{a}_{.1}, \mathrm{a}_{.2}$ dan $\mathrm{a}_{.3}$ value transformation

Table 2.

Laten Endogen Variable

\begin{tabular}{|c|c|c|c|c|}
\hline Laten Endogen Variable & \multicolumn{4}{|c|}{ Indicator } \\
\hline \multirow{5}{*}{ Project Performance $\left(\eta_{1}\right)$} & 1 & $\operatorname{Cost}\left(\mathrm{Y}_{1.1}\right)$ & 1 & Addendum Value Addition ( $\mathrm{b}_{.1}$ ) \\
\hline & & & 2 & Value of Fine $\left(b_{\cdot 2}\right)$ \\
\hline & 2 & Time $\left(\mathrm{Y}_{1 \cdot 2}\right)$ & & \\
\hline & 3 & Quality $\left(\mathrm{Y}_{1 \cdot 3}\right)$ & 1 & Contractor's Assessment (c.1) \\
\hline & & & 2 & Audit Findings $\left(\mathrm{c}_{\cdot 2}\right)$ \\
\hline
\end{tabular}

Remarks:

1. $Y_{1.1}$ is the indicator which came from $b_{.1}$ and $b_{.2}$ value transformation.

2. $\mathrm{Y}_{1.3}$ is the indicator which came from $\mathrm{c}_{._{1}}$ and $\mathrm{c}_{2}$ value transformation.

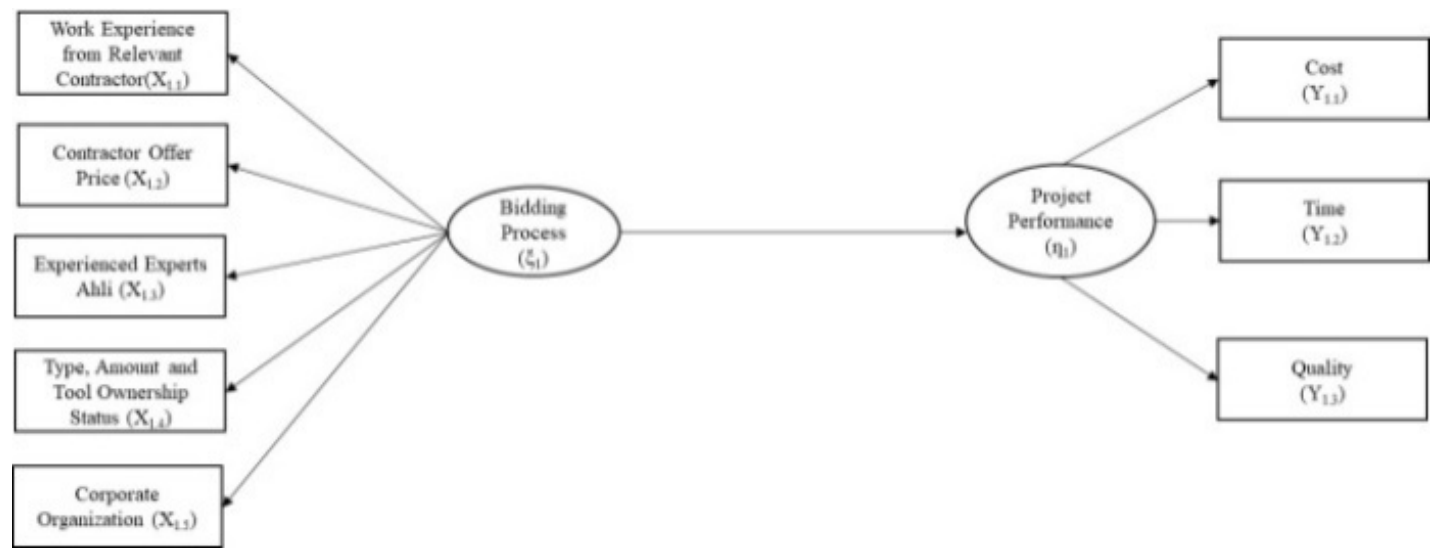

Figure 1. Path Diagram.

Remarks:

1. Indicator $\mathrm{X}_{1.1}$ based on the assessment of contractor's work experience in bidding process of 65 projects of PT Pelabuhan Indonesia III (Persero). Data is inputted in SEM PLS from value earned, compared with minimum and maximum values required.

2. Indicator $X_{1.2}$ based on the data comparison between contractor's price offer compare to Owner Estimate (OE) in 65 projects of PT Pelabuhan Indonesia III (Persero).

3. Indicator $\mathrm{X}_{1.3}$ based on individual assessment in the bidding process in 65 projetcs of PT Pelabuhan Indonesia III (Persero), data inputted in SEM PLS from value earned, compared with minimum and maximum values required.

4. Indicator $\mathrm{X}_{1.4}$ based on equipment assessment in the bidding process in 65 projetcs of PT Pelabuhan Indonesia III (Persero), data inputted in SEM PLS from value earned, compared with minimum and maximum values required.

5. Indicator $X_{1.5}$ based on Preparation of Execution Method, Preparation of Execution Schedule and ISO Certification Availability assessments in 65 projects of PT Pelabuhan Indonesia III (Persero). Data inputted in SEM PLS from value earned. Before input the value in SEM PLS, data indicator transformed using Pairwise Comparation.

6. Indicator $\mathrm{Y}_{1.1}$ based on project addendum data whether added addendum or less also value of fine in 65 projects of PT Pelabuhan Indonesia III (Persero). Data inputted in SEM PLS from value added addendum or less addendum compare to $10 \%$ addendum's maximum limit added with value of fine, compared to value of fine earned with $5 \%$ maximum value of fine. Before input the value in SEM PLS, data indicator transformed using Pairwise Comparation.

7. Indicator $Y_{1.3}$ based on data of audit findings and contractor's assessment in 65 projects of PT Pelabuhan Indonesia III (Persero). Before inputted to SEM PLS, data indicator transformed using Pairwise Comparation.

Performance is considered good when project performance indicators which include cost, time, quality, productivity, safety and environment in project is fulfilled. But in this case, the project performance monitoring is not yet running in PT Pelabuhan Indonesia III (Persero). Hence this research is expected to be able to determine the effect of bidding processes in PT Pelabuhan Indonesia III (Persero) in order to achieve optimum performance using Structural Equation Modelling (SEM).

\section{METHOD}

This research was conducted with quantitative method which is a research using statistical analysis towards empirical study approach in order to achieve, analyze and 
The $1^{\text {st }}$ International Conference on Business and Engineering Management (IConBEM)

February $1^{\text {st }} 2020$, Institut Teknologi Sepuluh Nopember, Surabaya, Indonesia

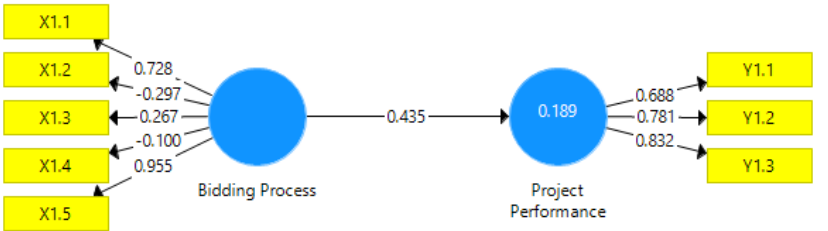

Figure 2. Path Diagram of The Equation

Table 3.

Step 1 of Loading Factor Value of Each Indicator

\begin{tabular}{ccc}
\hline Laten Variable & Indicator & Loading Factor \\
\hline Bidding Process & $\mathrm{X}_{1.1}$ & 0,728 \\
& $\mathrm{X}_{1.2}$ & $-0,297$ \\
& $\mathrm{X}_{1.3}$ & 0,267 \\
& $\mathrm{X}_{1.4}$ & $-0,100$ \\
& $\mathrm{X}_{1.5}$ & 0,955 \\
Project Performance & $\mathrm{Y}_{1.1}$ & 0,688 \\
& $\mathrm{Y}_{1.2}$ & 0,781 \\
& $\mathrm{Y}_{1.3}$ & 0,832 \\
\hline \hline
\end{tabular}

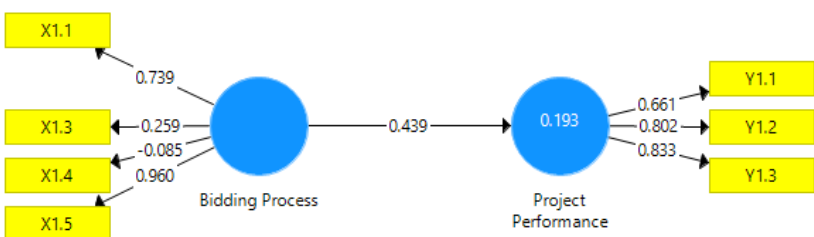

Figure 3. Path Diagram of The Equation Step 2.

Table 4.

Step 2 of Loading Factor Value of Each Indicator

\begin{tabular}{ccc}
\hline \hline Laten Variable & Indicator & Loading Factor \\
\hline Bidding Process & $\mathrm{X}_{1.1}$ & 0,739 \\
& $\mathrm{X}_{1.3}$ & 0,259 \\
& $\mathrm{X}_{1.4}$ & $-0,085$ \\
& $\mathrm{X}_{1.5}$ & 0,960 \\
Project Performance & $\mathrm{Y}_{1.1}$ & 0,661 \\
& $\mathrm{Y}_{1.2}$ & 0,802 \\
& $\mathrm{Y}_{1.3}$ & 0,833 \\
\hline \hline
\end{tabular}

demonstrate data processing in numeric form and conducted to certain sample or population. Final result of this research is numeric and concluded and explained in narrative. Hence this research is to see effects of bidding process towards project performance.

Variables in this research gained from literatures which then adjusted with bidding system in PT Pelabuhan Indonesia III (Persero). Suggested variables are Eksogen Variable which is Bidding Process, Endogen Variable which is Project Performance.

\section{A. Determining variable and indicator of research}

Variables in the research are obtained from literatures which adjusted with the bidding system in PT Pelabuhan Indonesia III (Persero). Suggested variables consist of Eksogen Variable that is Bidding Process, while Endogen Variable is Project Performance.

\section{RESULTS}

\section{A. Evaluation Outer Model}

Measurement model evaluation is used to understand the connection between laten variable with its indicators. The evaluation are validity assessment and reliability to recognize

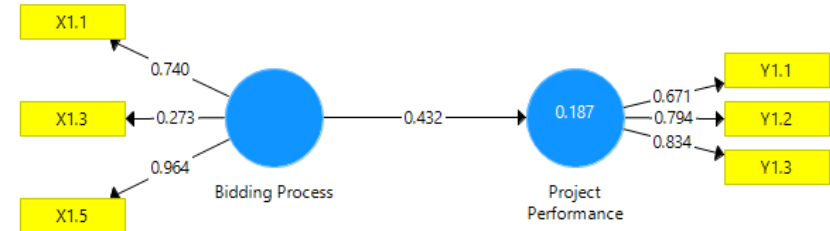

Figure 4. Path Diagram of The Equation Step 3.

Table 5.

Step 3 of Loading Factor Value of Each Indicator

\begin{tabular}{ccc}
\hline \hline Laten Variable & Indicator & Loading Factor \\
\hline Bidding Process & $\mathrm{X}_{1.1}$ & 0,740 \\
& $\mathrm{X}_{1.3}$ & 0,273 \\
& $\mathrm{X}_{1.5}$ & 0,964 \\
Project Performance & $\mathrm{Y}_{1.1}$ & 0,671 \\
& $\mathrm{Y}_{1.2}$ & 0,794 \\
& $\mathrm{Y}_{1.3}$ & 0,834 \\
\hline
\end{tabular}

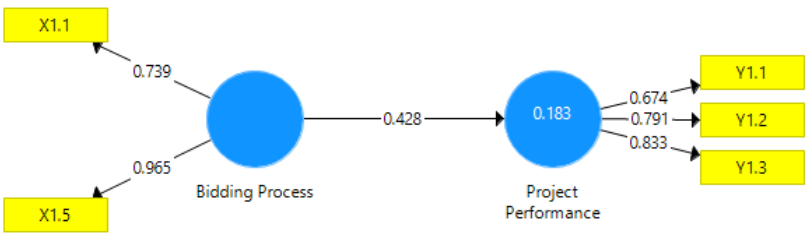

Figure 5. Path Diagram of The Equation Step 4.

Table 6.

Step 4 of Loading Factor Value of Each Indicator

\begin{tabular}{ccc}
\hline \hline Variabel Laten & Indikator & Loading Factor \\
\hline Bidding Process & $\mathrm{X}_{1.1}$ & 0,739 \\
& $\mathrm{X}_{1.5}$ & 0,965 \\
Project Performance & $\mathrm{Y}_{1.1}$ & 0,674 \\
& $\mathrm{Y}_{1.2}$ & 0,791 \\
& $\mathrm{Y}_{1.3}$ & 0,833 \\
\hline \hline
\end{tabular}

if indicators used are valid and reliable in defining laten variable.

a) Validity Tests

Validity tests can be done using convergent validity by observing the value of loading factor. Loading factor is value of correlation between laten variable with each indicators' variable. The loading factor value can be determined valid if has value of $\geq 0,5$. If there are indicators with loading factor value of $<0,5$, those indicators are taken out from the model. Figure 1 is Lane Equation Structural diagram between laten variables affecting project performance based on bidding process, and accommodate coefficient of loading factor in each indicator lane with its laten variable.

Result of the correlation value between laten variable with each of its indicators used for validity testing, is summarized in Table 3. Based on Table 3, there are invalid indicators in the laten variable of bidding process which are $\mathrm{X}_{1.2}, \mathrm{X}_{1.3}$ and $\mathrm{X}_{1.4}$ because the loading factor value is $<0,5$. Those invalid indicators are one at a time taken out from the model, therefore valid indicator is obtained. First indicator that is taken out from the model is $\mathrm{X}_{1.2}$ because it has the lowest value of $-0,297$ which indicator $\mathrm{X}_{1.2}$ is the contractor's price offer indicator.

Based on Table 4 can be seen that after taking out the invalid variable from the model, there are still invalid variables in the laten variable of bidding process which are $\mathrm{X}_{1.3}$ and $\mathrm{X}_{1.4}$ with loading factor value of $<0,5$. First indicator 
The $1^{\text {st }}$ International Conference on Business and Engineering Management (IConBEM)

February $1^{\text {st }} 2020$, Institut Teknologi Sepuluh Nopember, Surabaya, Indonesia

Table 7.

Reliability Test Results

\begin{tabular}{ccc}
\hline \hline Laten Variable & Cronbach's Alpha & Composite Reliability \\
\hline Bidding Process & 0,698 & 0,847 \\
Project Performance & 0,650 & 0,812 \\
\hline \hline
\end{tabular}

Tabel 8. Result of Hypothesis Testing on Measurement Model

\begin{tabular}{cccc}
\hline \hline Variabel Laten & Indikator & Loading Factor & t-statistic \\
\hline Bidding Process & $\mathrm{X}_{1.1}$ & 0,740 & 4,321 \\
& $\mathrm{X}_{1.5}$ & 0,964 & 28,174 \\
Project Performance & $\mathrm{Y}_{1.1}$ & 0,701 & 4,990 \\
& $\mathrm{Y}_{1.2}$ & 0,782 & 4,685 \\
& $\mathrm{Y}_{1.3}$ & 0,818 & 6,450 \\
\hline \hline
\end{tabular}

Table 9.

Results of Hypothesis Testing on Structural Model

\begin{tabular}{ccc}
\hline Laten Variable & $\begin{array}{c}\text { Original } \\
\text { Sample }\end{array}$ & $\begin{array}{c}T \text { - } \\
\text { statistic }\end{array}$ \\
\hline Bidding Process $\rightarrow$ Project Performance & 0,324 & 2,090 \\
\hline \hline
\end{tabular}

that is taken out from the model is $\mathrm{X}_{1.4}$ because it has the lowest loading factor value of $-0,085$ which indicator $\mathrm{X}_{1.4}$ is indicator of type, amount and equipment ownership status.

Loading factor value between laten variable with indicator on Figure 4, which counted based on data and summarized in Table 5. Based on Table 5, can be seen that after the invalid variable is taken out from the model, there is still invalid indicator in laten variable which is $\mathrm{X}_{1.3}$ because it has loading factor of $<0,5$ in which indicator $\mathrm{X}_{1.3}$ is indicator of experience of expertise.

Loading factor value between laten variable with indicator on Figure 5 which counted based on data can be seen in Table 6.

Based on table 6 can be seen that after the invalid variable is taken out from the model, all value of the loading factor in each indicators from five laten variables are valued $\geq 0,5$, therefore can be concluded that the convergent validity of each indicator variable is indicated valid in measuring the laten variable because the loading factor is achieved.

b) Reliability Test

Reliability test can be seen using composite reliability. The reliability test aimed to see if the indicators are reliable in measuring laten variable. The reliability can be measured with the value of cronbach's alpha and composite reliability. Indicators can be said reliable when achieve the value of cronbach's alpha is $\geq 0,5$ and composite reliability is $\geq 0,7$.

Table 7 above shows the value of cronbach's alpha and composite reliability from each laten variable of bidding process and project performance. The value of cronbach's alpha from three laten variables showed value more than 0,5 . Whereas the composite reliability value from five laten variables are more than 0,7 . This shows that each indicator variable is reliable in measuring its laten variable.

\section{1) Evaluation Inner Model}

Once the evaluation of measurement model is valid and reliable, the next step is to evaluate the structural model (inner model). The evaluation of structural model (inner model) is used to evaluate the connection between laten variables. Measuring tools used to evaluate the structural model in this research are $R$-square $\left(\mathrm{R}^{2}\right)$ dan $Q$-square Predictive Relevance $\left(\mathrm{Q}^{2}\right)$ values. The $\mathrm{R} 2$ value shows capability of laten exogen variable to explain the variety in exogen variable. Based on data in attachment 3 and software output in attachment 9, the $\mathrm{R}^{2}$ value in the laten endogen variable of project performance is $18,3 \%$. This means that the variety of project performance can be explained for $18,3 \%$ by laten variable of bidding process and project performance, while the $81,7 \%$ explained by other variable outside the model.

The value of $\mathrm{Q}-$ Square Predictive Relevance $\left(\mathrm{Q}^{2}\right)$ used to validate the prediction ability on the model. If the $\mathrm{Q}^{2}$ value close to value of 1 , therefore can be said that the structural model has relevance prediction. Based on calculation result using data in attachment 3 , obtained the value of $\mathrm{Q}^{2}$ is $18,3 \%$. This value is more than 0 which means that the result of project performance modelling with PLS has high predictive revelance.

\section{2) Hypothesis Testing}

The Hypothesis testing (resampling bootstrap) is used to show level of parameter significance from indicator variable in measurement model (outer model) and in structural model (inner model). Hypothesis testing in PLS encompasses testing to parameters of $\lambda$, $\beta$, and $\gamma$. Statistic test used is t-statistics or t-tests.

\section{3) Hypothesis Outer Model}

The parameter significance of outer model can be evaluated through resampling bootstrap procedure. The hypothesis used is as follows:

$H_{0}: \lambda_{i}=0$

Significance level of $\alpha$ used is $5 \%$, so that the t-table value is 1,96 . Table 9 is t-statistics testing result on structural model (inner model). The t-statistics value is counted based on data.

Table 9 showed that t-statistics value from laten variable of bidding process to performace is worth of 2,090, which is higher than the t-table which is 1,96 . Therefore can be concluded that the effect is significant, or the bidding process has positive influence to project performance and its worth of 0,324 .

\section{CONCLUSION}

Conclusions from analysis and study on the influence of laten eksogen variable of bidding process on laten endogen variable of project performance using Structural Equation Modeling-Partial Least Square (SEM-PLS) are as follows:

Analysis results using SEM-PLS method has achieve the criteria of validity and reliability assessment with 2 bidding process indicators and 3 project performance indicators. Project performance variable R2 is $18,3 \%$.

Structural model achieved with SEM-PLS model based on data in attachment 3 is when laten exogen variable of bidding process increase one unit and other variables considered constant, then laten endogen variable of project performance will increase by 0,324 .

\section{REFERENCES}

[1] P. E. Eriksson and M. Westerberg, "Effects of cooperative procurement procedures on construction project performance: A conceptual framework," Int. J. Proj. Manag., vol. 29, no. 2, pp. 197-208, 2011, doi: 10.1016/j.ijproman.2010.01.003.

[2] Y. A. I Nyoman, H. A. Rusdi, and A. W. Mohamad, "Influence of bidding strategy on project performance in construction," $A d v$. Nat. Appl. Sci., vol. 9, no. 5, pp. 65-71, 2015. 
The $1^{\text {st }}$ International Conference on Business and Engineering Management (IConBEM)

February $1^{\text {st }} 2020$, Institut Teknologi Sepuluh Nopember, Surabaya, Indonesia

[3] A. Umulisa, M. Mbabazize, and J. Shukla, "Effects of project resource planning practices on project performance of agaseke project in Kigali, Rwanda," Int. J. Bus. Manag. Rev., vol. 3, no. 5, pp. 29-51, 2015.

[4] M. A. Wibowo, I. N. Y. Astana, and H. A. Rusdi, "Dynamic modelling of the relation between bidding strategy and construction project performance," in Procedia Engineering, 2017, vol. 171, pp. 341-347, doi: 10.1016/j.proeng.2017.01.342.
[5] Z. Isik, D. Arditi, I. Dikmen, and M. T. Birgonul, "Impact of resources and strategies on construction company performance," $J$. Manag. Eng., vol. 26, no. 1, pp. 9-18, 2010, doi: 10.1061/(ASCE)0742-597X(2010)26:1(9).

[6] B. W. Soemardi, R. D. Wirahadikusumah, and M. Abduh, "Pengembangan model penilaian kinerja jasa konstruksi," in Prosiding Conference on Toward Sustainability Civil Engineering Practice, 2006, pp. 25-26. 